\title{
Foreign Language Education in Lebanon: A Context of Cultural and Curricular Complexities
}

\author{
Nahla Nola Bacha \\ Humanities and Social Sciences Department, Lebanese American University, Byblos, Lebanon \\ Email: nbacha@lau.edu.lb \\ Rima Bahous \\ Education Department, Lebanese American University, Beirut, Lebanon \\ Email: rbahous@lau.edu.lb
}

\begin{abstract}
Knowing more than one or two languages has always been a natural consequence of cultural exchange. Thus educational institutions the world over have placed teaching/learning of languages high on their agendas as they find the need for their students to be competitive in the global career arena. The communication among different cultures and the efforts of education have added to the multi lingual/culture of many countries. However, the growth of this multilingualism/multiculturalism is not without its questions concerning complexities involved in what attitudes do the learners hold towards learning languages, which languages should be taught and whether these languages would 'complex' the learners in finding their own native language 'inferior'. This study examines these complexities in Lebanon, a country long known for its multi lingual/cultural makeup, Specifically, the paper gives an overview of the cultural influences in the country over the past century and how this was responsible for the adoption of the foreign languages, mainly French and English, that coexist in the country today along with Arabic, the native language. The paper focus on the consequent educational trends in teaching/learning languages in noting the new National Curriculum changes in the 1990's after the civil war and how the policies were implemented at both the pre and tertiary sectors. Cultural, attitudinal, motivational and language acquisition factors are discussed in how the French medium and English medium schools accounted for them in their language curricula and how they impact learners' language development. The researchers debate whether the teaching/learning of foreign languages may eventually lead to the 'decline' of the national language, the latter being a 'complex' for the many, which is a concern that most countries are facing these days.
\end{abstract}

Index Terms - Lebanon, multilingualism, multiculturalism, language and education, languages in Lebanon, EFL/ESL

\section{INTRODUCTION}

Lebanon, a 'small' country located in the Middle East near the Mediterranean Sea, offers a 'gold mine' for language study considering its unique multilingual and multicultural make up. One does not have to travel much there to hear Arabic, French, English, Armenian or other languages spoken everywhere. For many who come to our shores, the complexity of the language situation is appreciated and praised, but at the same time with the foreign languages being spoken in many sectors, one could wonder whether it is due to a complex that the people have concerning their own native language Arabic and thus pride themselves in knowing other languages such as English and French. Indeed, the Lebanese have been praised for their hospitality, their cultures and languages.

In this paper we share our language story and show how the Lebanese have addressed the multi lingual/cultural milieu in developing their language education in spite of the outside influences, the war and the demographic diversity. It is significant to show how a country characterized by a multi lingual/cultural attempts to deal with the complexities in the educational sector. It is believed that it is here in education that 'world citizens' are produced that can and should communicate across various cultural communities.

Most research in Lebanon is done locally by Lebanese international scholars (referred sometimes in the literature as 'gloclocal'). Specifically, we present how the history of Lebanon has been marked by its profound multilingual/multicultural profile, and the main issues involved in foreign/second language teaching at both the pre and university levels, with emphasis on teaching/learning English in both the private and public sectors.

\section{The Multilingual/Multicultural MaKeup of the Lebanese}

Lebanon's unique position between East and West makes it very receptive to other cultures and languages. The teaching of languages other than the native language, Arabic, in pre-university education has been influenced by the presence of foreign influences which went through three phases (Frayha 1999). During the first phase, foreign missionaries between the $17^{\text {th }}$ and $20^{\text {th }}$ centuries were relatively free to use the language of their home countries and 
establish schools which were products of the Ottoman-European relations. It was the French and British who were mainly active during this period, the former being more so. The second phase, during the French Mandate (decree no. 2079, dated June 20, 1924) imposed the teaching of Arabic and French languages as compulsory in private schools (see Jarrar, Mikati, Massialias, 1988). In effect, schools teaching English and Arabic had to include the teaching of French. At that time, French foreign schools constituted $80 \%$ of the total in the country. It was with the third phase, after the independence of Lebanon in 1943 from French governance, that schools teaching English as the second foreign language increased (Atiyeh 1970). However, the number of students who studied English did not increase significantly until the 1970's when English began to become an important means of communication world wide. From then on, many schools opted to introduce a trilingual system with English as a third language. At the university level, the American University of Beirut, one of the leading English medium university in Lebanon and in the Middle East, founded in 1866 , had Arabic as the medium of instruction until 1882 after which studies began in English (see Abu Ghazaleh, 1990 and Zachs, 2005 for a comprehensive account).

A word on second versus foreign language teaching in relation to Lebanon is in order at this point. Yazigi (1994) explains that in Lebanon while Arabic is the native language of most of the Lebanese, French is referred to as the second language as it is taught in most schools. It is the medium of instruction in French sponsored schools and universities and it is also the language spoken by people in the community outside of the classroom. English, on the other hand is mainly referred to as a foreign language as it is the third language that students study in French medium schools. In American and British sponsored schools and universities where English is the medium of instruction, English is referred to as a second language while French being the third, is referred to as a foreign language. However, unlike French, English in the community is still referred to as a foreign language as it is not usually the language spoken outside the classroom. Yazigi (1994) applies this distinction between foreign and second language to Lebanon. She notes that English is taught as a foreign language in Lebanon at large and at the university in particular as Arabic, French, Armenian or other languages of communities, rather than English, are the languages of daily use.

The teaching/learning educational system in which more than two 'other' languages is now compulsory in the school systems is by no means an easy task even for the language gifted Lebanese (Frayha 1999). Much effort is being exerted in teaching and learning languages in Lebanon and English is increasingly becoming a part of its life, whether in studies or communication. All three languages are important in Lebanon in education, but it is French and Arabic that are used mostly in the social and business world. Recently, English is being viewed not only as another option in which students can follow a course of study, but one that offers 'prestige'. English is also increasingly viewed by many Lebanese as an important tool to further one's studies abroad in the US, UK Australia, and Canada. This, of course, is related to the fact that many have immigrated during the civil war period and still do so to this date in great numbers to seek a better future.

In addition, over the last three decades, foreign workers have increased in Lebanon adding Philippine, Amharic, Sinhalese, Indian, Pakistani and Nepalese to name the main languages. But it is English and French that are the main foreign/second languages brought by the American and French influences in both education and public sectors with the French influence being more prevalent.

On the individual level, the language and identity situation is quite a complex one. It is not unusual for a Lebanese national to have Armenian as a first language, Arabic as a second, English a third, French a fourth and possibly a knowledge of one other language such as Spanish or German. Although Arabic is the native language of most Lebanese, it is very common for people to use French during daily conversation (English increasingly used recently), and it is also 'natural' that in almost all sectors of society, a mixture of languages is in daily use with frequent code switching among languages. In fact, the use of French and English over Arabic in educational, social and business circles is becoming more evident; a reflection and result of the receptiveness of the Lebanese to Western culture and their travels abroad. The language situation is also related to the literacy level (89.6\% of adults and $98.7 \%$ of youth) in Lebanon which is relatively high considering the unstable periods that the country has witnessed. Bashur (2004) reports that Lebanon has the highest literacy rates amongst its neighboring countries of 97.5\% between the ages of 15-24 in 2000 and Haidar (2002) adds that Lebanon has the best universities and publishing houses in the Arab world. Moreover, in 2009, Beirut became the World Book capital.

Cultural and political factors have influenced to different extents the educational system in Lebanon and have made any account of the latter quite a complex task especially during the period of the Lebanese civil war and its aftermath (Serriyeh 1989). However, an attempt will be made to give an account of the language education in Lebanon and the growing importance of English separate from these factors as much as possible. This will be done in describing language teaching and learning in relation to the framework of the country's general educational background, the preuniversity and university educational systems; learning methodology, cultural and motivational factors toward language learning, and teacher language education.

\section{NATIONAl LANGUAGE DEVELOPMENTS}

The new National Language Curriculum, approved by the Council of Ministers in 1994, made it a requirement for all schools to teach a second 'foreign' (i. e. other) language. That is, schools in addition to Arabic, should have either English or French as a first 'foreign' language in addition to a second 'foreign' language. The fifteen years of war, 
1975-1990, interrupted growth and development in the educational sectors quite severely, but since 1990 there have been plans set up for the educational reconstruction of Lebanon (Frayha, 2003). Zouain (1994) outlined specifically at the post war period the work needed to be done at both the high school and university levels which entailed building infrastructures, educational programs, training qualified personnel, and a whole new national curriculum. It is in this context, that educators have made efforts to review and implement a revised language curriculum at both the preuniversity and tertiary levels (Shaaban \& Ghaith 1997) sponsored by the Ministry of Education in conjunction with the Center for Education Research and Development. The work, based on modern theories of curriculum design and teaching methods, has entailed implementing a new national curriculum mainly for the public sector involving a multiplicity of interrelated learner, teacher, subject, and contextual factors (see BouJaoude \& Ghaith 2006; authors; 2009 for a review on the educational system).

In the new national curriculum, the learning of the Arabic language and the first foreign language (English or French), consists of 6 periods/week each totaling 12 hours/week, and the second foreign language (English or French) 2 periods/week.

Related to the learning of English and applicable to all three languages, the purpose of the Curriculum is designed for academic achievement, social interaction, and cultural enrichment based on five main principles: communication, context variation, cultural awareness, interactive learning, integration of skills.

The language curriculum is now in its 13th year of implementation, and although there are no rigorous results as yet to the extent of the effectiveness of the new approach, students and teachers' experiences have indicated a general positive attitude in the learning situation (BouJaoudeh \& Ghaith, 2006). However, the curriculum is quite challenging for those who have been following traditional methods. Many teachers find it often difficult to adapt to a system in which new methodology and time constraints need to be constantly addressed throughout the regular teaching/learning process. Thus, teacher training has been very high not only on the Ministry of Education's agenda, but also on agendas of many private institutions and universities. Since more students are currently opting to continue their higher studies in English medium universities, considering them the 'best', addressing English Language teacher training has become a very essential part of the curriculum.

The new curriculum has not been without other challenges. There have been debates on the effectiveness of the new curricular in a Lebanese context in bringing about positive changes in 'individual and social integration' and to revise the English curricular to be in conformity with recent teaching/learning models at a time of international communication and globalization. Inati (1999) emphasizes the value of the reform in offering the relevant language background for university education, future careers, international communication and fostering critical and analytic minds. Adapting to the new curriculum has been difficult for those teachers who prefer their old ways claiming that through the latter better results in student's learning are obtained (personal communication with teachers). Mikati (2000), however, highlights the importance of the thinking skills emphasized in the new curriculum. She argues for the importance of involving students in activities that draw on the higher order skills of application, analysis, synthesis, evaluation in students' cognitive development in learning other languages that the New National Curriculum is emphasizing. A final note is worthy of comment. Education in Lebanon is considered very important and high educational attainment is prestigious: families do their utmost (even selling their land) to educate their children. The amount placed on schooling is $8.1 \%$ of the total public expenditure with all levels receiving equal attention. Pre-primary education is mostly sponsored by privately owned institutions and day care facilities. Zouain (1994) confirms that 'education ranks very high on the social scale of values...' (p. 3351).

\section{LANGUAGE POLICY--PRE-UNIVERSITY SYSTEM}

Students usually begin learning the second languages in the elementary classes, which are the media of instruction for all the school subjects. If most of the curriculum uses French as the medium of instruction, students are referred to as being French educated and if most use English, they are referred to as English educated. Being in either system of education does not exclude study of the other language as a third language referred to as a 'foreign' language. For example, a French educated student would also be required to study 3-6 hours per week of English language and vice versa (Shaaban \& Ghaith, 1999). Zouain (1994) comments on the study of languages in Lebanon that more than half of the Lebanese people are bilingual, $75 \%$ of students learn French as a second language and 25\% English especially in the private schools. In fact, it was the private schools that remained open during the most difficult times in Lebanon and were the main source of education when the country was in crisis (see Zakharia, 2004). Most government institutions were severely affected and many closed for long periods.

At the end of the intermediate school period (Grade 9), students are issued with the Brevet Diploma. At the completion of the high school (Grade 12) years, a Baccalaureate Diploma (French and/or Lebanese) is awarded and students are then eligible for university study.

According to statistics from the Lebanese Ministry of Education, 62.5\% of all Lebanese schools offered French as a second language in the school year in 1999-2000 which decreased to 55.8\% in 2005-2006 and schools in which English was offered increased from $19.7 \%$ to 21.6 percent. Also, schools giving both English and French increased from $17.8 \%$ in 1999-2000 to 22.6\% in 2005-2006 (Beirut Daily Star - On-Line News retrieved March 30, 2009 http://www.beirutonline.net/portal/article.php?id=3142). 
Wissam Chidiak, a speech therapist, stated (Daily Star, 2009) that with the increasing importance of English, the number of children who attend tri-and multilingual schools as well as preschools has also increased. Another confirmation to the growing importance of English but a concern for the decrease for French is made by a founder of a preschool establishment in Beirut, who stated that 'Parents realize that English is getting more and more important in a globalized world, but at the same time, they do not want children to lose the French language' (Daily Star, 2009).

Further, a clinical psychologist also noticing the trend in language acquisition in Lebanon remarked on the learning of three languages by children which is typical in Lebanon stating 'Imagine a two-and-a-half year old toddler who is able to communicate in three different linguistic codes, even though they are not perfect. Imagine a child who can watch cartoons in English, then switch to a French channel and at the same time talk to his parents in Arabic' (Daily Star, 2009).

While most schools in Lebanon still teach French as a second language, the number of students learning it has fallen by nearly 10 percent over the past decade, according to the Lebanese Ministry of Education (Daily Star, 2009). 'Today, there are a lot of new English-language schools and many schools that follow the French program are opening English departments' stated Denis Gaillard, the head of the cultural section at the French Embassy in Beirut, and admitted that 'it was becoming more of a challenge to promote the language of Moliere in a region where English is omnipresent' (Moussaoui 2009).

However, 'The demand for French remains strong,' said Olivier Garro, head of the Beirut-based Agence Universitaire de la Francophonie 'In the Gulf region, speaking French has become an advantage. Someone who speaks three languages is sure to be chosen for a job over someone that doesn't,' he added. Moussaoui (2009) reports on a young girl, Anna Abu Jaoude, 19 years of age who stated that she was taking French courses in Beirut in the French Cultural Center in order to be competitive and said 'There is no question that English is easier to learn and offers more opportunities, but French is a plus'. A professor at one of the universities in Lebanon told the newspaper, Daily Star, 2009 that he believes that 'French will not disappear because it is part of our culture. We still publish quite a bit of literature in French and our judicial system is largely inspired by the French system.'

There is also concern that Arabic has been seconded or placed on an equal footing to these other languages and which may decline and/or negatively influence the Lebanese' national identity (Joseph, 2004). Some researchers (Nasr, 2000, Maalouf-El-Alfy, 2000; Bacha, 2010), however, show how some poets and writers bring together the culture of the East and West through their writings and the study of literature.

\section{LANGUAGE POLICY--THE UNIVERSITY SYSTEM}

There are several institutions of higher learning in Lebanon. The main foreign ones are the American University of Beirut (AUB) founded by American missionaries in 1886 and the Lebanese American University (LAU) founded by American missionaries in 1924. These two universities, modeled on the American type universities, have been trying to keep the standard of education equitable to those in similar institutions in the US as well as make developments in order to keep them at the cutting edge and compete with the many 'less prestigious' universities who charge much less fees and that are mushrooming in the country. Some of the latter are receiving international monetary or/and academic support from European and US institutions. Nauffal and Nasser (2007) report on a comparative study of the organizational cultural qualities of American Universities and American-based universities in Lebanon and conclude that "A supportive management culture - one that encourages the introduction of innovative teaching methods, the use of modern technologies, the production of collective research and continuous self-appraisal and evaluation - may help these young universities create a niche for themselves within Lebanese and regional communities" (p. 59).

Two well-established universities are the French university, Saint-Joseph University, founded in the late 19th century by the French, and a state university, The Lebanese University which has the largest student body in country. Both AUB and LAU use English as the medium of instruction and follow the American system of course credits and semesters. Both universities have an English as a Foreign Language Program (EFL) similar to those at comparable US universities, which prepares students to cope with their academic course work.

Many private institutes offer pre-university language courses in English and French (as well as additional languages such as Spanish, German, and Italian for higher studies abroad or for interest) and some universities offer Remedial language courses, which cater to students who have not passed the required entrance exams. As part of program development and accreditation requirements at the university level, the Remedial Programs have begun to be assessed for their efficiency in helping students perform successfully in higher studies (e.g. Nasser \& Goff-Kfouri 2008).

\section{CULTURAL INFLUENCE ON LANGUAGE LEARNING}

Cultural background has been an influencing factor on learning. In the Lebanese case, the collective type culture in contrast to the individualized culture of the West is very apparent in the classroom (Ayyash-Abdo, 2001). In the former, the teachers are the givers of knowledge and as such students cannot question their authority but obey their directions. There is very little exchange and discussion in classrooms and group work where peers are given leadership roles is not looked upon by students as a learning experience; whereas, in more Western type classroom teaching and learning is carried out in a more informal manner and the learner is the center (Kibbi 2003). 
The multicultural make up of Lebanon makes it a place similar to the US in that we can see it as a possible 'melting pot'; but unlike the West, the people from each 'community' strongly abide by their way of life and traditions although in educational spheres there is an attempt to develop tolerance, positive attitudes to others and building of cooperative and team spirit attitudes. Khoury (2003) reports on the complexity of defining culture, but attempts to give a standard 'small' view based on the perceptions of theorists in the field who view culture '... as processes in the making ... dynamic...involve change, modification, and dialogue... agents are skilled at negotiation and problem-solving ... and these [provide] basic guidelines for behavior..' (pp.130-133). Applied to the teaching of languages in the national curriculum, Khoury (2003) reports that the curriculum focuses on '....creating a citizen who is proficient in at least one other language ... to promote openness to and interaction with other cultures' (Khoury, 2003, p.131). Translated into the teaching of second languages, cooperative content-theme based activities are drawn upon which focus on developing students' critical thinking and problem solving skills on issues relating the target language.

Chami-Sather and Kretscher's (2005) studies on Lebanese and American elementary children indicated how the cultural background affected the speaking situation in solving problems. The Lebanese children would speak a great deal and constantly interrupt one another and show eagerness; while the American children would wait for their turns and quietly discuss the issue. They state that "Focusing on the cultural linguistic behavior in academic settings, linguistic moves, nonverbal clues, and using that kind of information to build qualitatively facilitating educational processes would provide a great achievement of students ...if well managed, might become aiding tools for teachers in rethinking their classroom management for better results" (p.29).

Gaining this cultural awareness and adaptability, according to the authors, contributes to better student learning. Joudi, Karaky, and Kurdi (2003) in their qualitative study on 7-8 year old from a middle to low class background in one of the schools in Beirut, Lebanon, observed during group and class activities in learning English that the students were highly engaged in the lessons as the personality of the teacher was positive and friendly, both culturally determined characteristics when teaching children and would only speak in English as directed by the teacher. However, the students code switched between Arabic and English in student group activities often resorting to their L1 Arabic native tongue. The children would also call the teacher "Miss" in referring to her as teachers in the Lebanese context are highly respected and are always addressed formally which is a culturally determined practice. The authors conclude that content and style of learning a second language are determined by cultural factors, but recommend larger scale research to confirm and validate these preliminary results.

Shaaban and Ghaith's (2002) ethnographical study through a survey on 176 randomly chosen university students showed that the cultural, religious and socio-economic class influenced their perceptions of the vitality of the three languages: Arabic, French and English. Results indicated that Arabic was vital for national identity and communication with family, French for entertainment and elementary education, and English for higher studies, technology and commerce and that the Muslim sample spoke English more than the other religions in the samples.

Studies (El-Hussari, 2007; Diab, R. 2000) on raising cultural awareness as it is defined in the new national curriculum and which basically deals with developing students' knowledge and tolerance of international diversity, report that classroom teachers need to implement relevant activities in the classroom. Ghosn (2007) has argued for using literature, specifically stories in the classroom, to raise young learners' cultural awareness and civic responsibility. She strongly believes that through the students reading texts and being involved in group activities, the young learner in Lebanon can be better oriented to the values of a democratic and peace building life that they need in a country torn apart by war and sectarian struggles. Akl (2007) reports that the infrastructure of Lebanese schools and universities is influenced by the multicultural/multilingual profile of Lebanon, which causes many conflicts and disagreements. She attempts to give solutions to this by comparing the Lebanese educational system to that of the Western liberal-secular educational system and concludes on the significance of activities that resolve conflicts. Author (2010) investigates students' perceptions in one university EFL Program on the novel over a semester and how they view it helping in their developing their English language skills. The students' reported positive feedback concerning their improvement as well as widening their cultural awareness of peoples and places.

A very important aspect of teaching culture in the classroom is the concern of some researchers as to how to preserve the 'national culture' and at the same time expose the students to the cultures of the West, which also is a difficult task (Diab, R. 2000; Diab, N. 2000; Maalouf-El-Alfy 2000; Nasr 2000). Maalouf-El-Alfy (2000) reports on the difficulties she has faced in university classes where the students do not seem to respond positively to the literature through which culture is transmitted and often do not see the relevance to their studies or lives. Maalouf-El-Alfy (2000) recommends a reader-response method that she has successfully experimented with in which students would freely react to a piece of literature and then the differences and similarities to the Lebanese culture discussed in a comfortable and tolerant class atmosphere.

This difficulty is also coupled with the fear that some teachers and researchers have that there may be a national cultural 'distinction' due to the strong foreign influence. Nasr (2000) recommends that one way to keep the Lebanese cultural heritage alive and thus its language is through the study of Lebanon's literature which 'can address international issues of global appeal and at the same time nurture the specific national heritage' (p.49). She illustrates this through the poems of May Rihani, a famous Lebanese writer, who traveled to over fifty countries and wrote poetry in which both East and West meet. 
Nasr (2000) argues that although we live in a age of globalization and students are exposed in their lives at school and society to the many cultures especially the West and to English, the danger of losing their national identity and culture can be lessened by their reading literature of writers who are bridges between the East and West. The works of May Rihani who has lived in the West and East and writes in both Arabic and English illustrating well the need to expose students to the diversity of cultures in the modern world and at the same time preserves the culture of the homeland. Nasr (2000) gives an excerpt from one of her poems written while Rihani (1992, Washington D.C., Platform International, p.72 translated by Nasr 2000) was in Washington D.C. during the war in Beirut, Lebanon showing this bridging between two cultures through a poem.

$\cdots$

And the sky scrapers of New York

...

Rain carries me there

To my village

Another excerpt from her travels in a poem 'I Travel' (Rihani 1992, p.7 translated by Nasr 2000) shows the bringing together of the cultures through language.

I travel

...

On the other end lies part of here

The borders fade when I tolerate

...

The languages are understood when I listen

The globe becomes smaller....

Saad Khalaf's (2009) research is particularly interesting in this context on narrative reports from students who come from mixed nationalities and cultures attending a creative writing course at the American University of Beirut. They tell of their problems and issues of 'belonging' and how through writing in English they are able to express to one another their cultural alienation to the cultural heritages of which they are part and to reflect on how the situation in the country has left them 'homeless'; yet they can communicate this common feeling and find comfort in expression through language.

\section{MotiVAtional AND ATtitudinAL INFLUENCES ON LANGUAGE LEARNing}

Students in both high school and university have different attitudes towards foreign language, which affects their motivation. For example, many believe that studying foreign languages is a passport to the foreign universities and acceptance to higher institutions of learning abroad. Thus, they are highly motivated to learn foreign languages. Although students may need to enroll in government public schools and the government Lebanese University where Arabic is mostly stressed, as they cannot afford the higher tuition fees of the private schools and universities, they try hard to learn other languages in outside language centers or with private teachers. Also, the Lebanese look upon the foreign schools and universities as being prestigious by comparison and having a better educational system than those that are Lebanese supported mirroring that of the West. Diab, R. (2000) indicated that male learners are instrumentally motivated to learn English for career purposes, while women along with this also see the advantage of the social prestige that knowing English gives, perhaps mirroring the neopatriarchal Lebanese society in which males are dominant (Ayyash-Abdo et. al. 2009).

Akar's (2007) recent study of two pre-university classrooms on their perceptions of how they learn and their attitudes towards learning and citizenship, indicated that they valued humanistic and democratic principles while favoring traditional methods of learning such as memorization and teacher autonomy. This paradox, claims the author, is a challenge to the students in their learning experiences. These citizenship studies go hand in hand with leadership skills often fostered in language classrooms through critical thinking and problem solving activities. Greenfiled and Akkary (1998) carried out a qualitative study on principals in private and public secondary schools and through questionnaires, interviews and observations of 33 principals found different perceptions of their roles between the Lebanese and the American and neighboring contexts. Principals from the private sector tend to have more authority than those in the public sector who have to enforce the decisions made by the Ministry. This is similar to the situation in other countries such as Jordan and Saudi Arabia. However, when compared to their American counterparts, the religious and sociocultural factors influence the principals in Lebanon, which is not the case in the American model. These roles affect language policy and methodologies in the classroom depending upon type of school and context.

Students' attitudes and beliefs towards foreign languages have been investigated in the Lebanese language context and indicate that teachers should be aware of their students' beliefs and attitudes towards learning a foreign language and what type of feedback they expect in the learning process (Diab, 2010; Diab 2006, 2009; Yazigi 1994). Diab (2006) study is based on 284 university EFL students who filled out a questionnaire in four parts: '1) beliefs about foreign language learning in general, (2) beliefs about learning English, (3) beliefs about learning French, and (4) beliefs about the learning of different languages in Lebanon' (p. 84). The main results indicated that students are instrumentally motivated to learn English, which they consider 'easier' than French to learn and they consider English more important 
than the other two languages. The results further showed that the beliefs of the students were related to the political and socio-cultural situations in teaching foreign languages in Lebanon. Yazigi's (1994) also indicated the relation with the teaching context in Lebanon that students are more instrumentally motivated to learn English and value it as a passport to a better learning future. Diab's (2009) study on 30 EFL teachers who did not have extensive teaching experience in an English medium university, showed that often times teachers have beliefs of student learning that are not in line with those of their students. For instance, she found that teachers believe that learners should attain near native English accent and student work should be edited for total accuracy. Diab (2009) recommends that teacher workshops could raise awareness of the teachers' role and expectations more in line with students' acquisition of a foreign language. There seems to be a more interactive teaching/learning model coming alive in foreign language classrooms in Lebanon among students, peers and teachers, which shows gains in language proficiency. Sinno's (2008) study at one English medium university indicated that students' were motivated extrinsically to learn English as it opened doors to study and work on an international level and that political views did not negatively impact their learning and using the language, whether French or English.

\section{LANGUAGE ACQUISITION INFLUENCING FACTORS}

Language teachers in Lebanon have often questioned which language should be learned first. Since Arabic is their home language in most cases, others being Armenian, Italian, French. Author (1999) recommends they learn their mother tongue first and then the other language by five and give them opportunities to use it. However, this is not the case. Young learners are often acquiring the second language these days more rapidly than their mother tongue as even at home, the parents are speaking the second languages, English and/or French. It is indeed a complex multilingual situation.

Thonhauser's (2000) study in interviewing six Lebanese individuals shows the complexity of the multilingual context in Lebanon and notes that the situation of diglossia adds to it. He reports that many prefer to follow a career in Englishmedium universities as it gives them more career opportunities. Also, they prefer to write in English and/or French rather than in Arabic as the latter has to be in the literary form, which they do not like. Shaaban and Ghaith (1999) report on the bilingual, trilingual and multilingual profile of the Lebanese and the code-switching that is highly predominant in both private and public sectors, a natural characteristic of the Lebanese. However, they do voice the concern of researchers that that this multilingual situation may be negative more than positive in the sense that it may lead in language education to those who may not have any real proficiency levels in any of the languages and that Arabic is losing popularity compared to the foreign languages (p.12). Yet, they end on a more positive tone that with the declining economic condition, more students are joining the state Lebanese University and public schools where Arabic is the medium of instruction which may restore Arabic on equal footing with the English and French. Ghaith and Shabaan (1996) also note that "... despite the spread of French and English as instructional languages, the strength of both languages remains limited to the context of education, and are not widely used for ceremonial, societal and communicative functions" (p.104).

\section{CONCLUSION}

Lebanon's multicultural and multilingual profile has made it a country of cultural and lingual diversity. Its language educational system and policies reflect this profile and have had a long and complex history, one that has gone through many phases influenced by socio-political factors and outside influence of missionaries who brought their languages and educational systems and policies. Although the national language remains Arabic, the medium of instruction at schools and universities depends largely on those who support and administer the institution. The two main second languages remain English and French with many other additional languages also spoken and used for educational instruction. It is a plethora of peoples carrying with them their linguistic and cultural characteristics. Education in Lebanon is a very important part of the country's prosperity and English is quickly becoming the dominant second language, a means for prestige, study and communication (Shaaban \& Gaith, 1999). Not a complex, but a way to survive and compete on the global arena.

It is in this Lebanese language context that teachers and students come together to teach and learn, to acquire the relevant language background and to be exposed to the different cultures that surround the language learning experience. Our language story ends here for a while with the learner carrying a 'language and cultural baggage', always becoming heavier, giving researchers, practitioners and curriculum designers more food for stories to tell of the inter relationships among the learners' languages and cultures and the curricula that attempt to address these and the learner that is 'produced' to communicate on the global arena which many travelers have found less and less complex as they continue their travels to our shores.

\section{REFERENCES}

[1] Abu Ghazaleh, A. (1990). American missions in Syria: A study of American missionary contribution to Arab nationalism in nineteenth century Syria. Vermont: Amana Books. 
[2] Akar, B. (2007). Citizenship education in Lebanon: An introduction into students' concepts and learning experiences. Educate 7.1, 2-18.

[3] Akl, L. (2007). The implications of Lebanese cultural complexities for education. Mediterranean Journal of Educational Studies 12.2, 91-111.

[4] Al-Khatib, H. (2003). Language variation and code-switching in bilingual performance. In R. Bahous \& N. N. Bacha (eds.), Proceedings of second regional conference on language and change.. Beirut: Librarie du Liban, 121 -126.

[5] Atiyeh, N.N. (1970). Schools of Beirut. In Beirut College for Women Beirut: Crossroads of cultures. Beirut: Libraire du Liban, $133-166$.

[6] Ayyash-Abdo, H. (2001). Individualism and collectivism: The case of Lebanon. Social Behavior and Personality, 29, 503-51

[7] Ayyash-Abdo, H., Bahous, R. \& Nabhani, M. (2009). Educating young adolescents in Lebanon. In S. Mertens, V. Anfara, \& K. Roney (eds.) Handbook of research in middle level Education: An international look at educating young adolescents. North Carolina: Information Age, 24 - 46.

[8] Bacha, N. N. (2010). Teaching literature in English as a foreign language classrooms: A study of student attitudes. International Journal of the Humanities 8.1, 47-63.

[9] Bahous, R. (1999). What language should a Lebanese child learn first? Paper presented at the Lebanese American University 'Multilingualism and Multiculturalism in Lebanon Conference, Beirut, Lebanon, December.

[10] Bashur, M. (2004). Higher education in the Arab states. Beirut: UNESCO

[11] BouJaoude, S., \& G. Ghaith (2006). Educational reform at a time of change: the case of Lebanon. In J. Earnest \& D. Tragust (eds.) Education reconstruction in transitional societies. The Netherlands: Sense Publishers, 193 - 210.

[12] Chami-Sather, G. \& R. Kretschmer. (2005). Lebanese/Arabic and American children's discourse in group-solving situations. Language and Education 19.1, 10-31.

[13] Daily Star - On-Line News retrieved March 30, 2009 http://www.beirut-online.net/portal/article.php?id=3142 (accessed 30/10/2010)

[14] Diab, N. (2000). Stimulating effective language learning through cultural education. In N. N. Bacha \& R. Bahous (eds.) Proceedings of the first regional conference on language and change. Beirut: Librarie du Liban, 61 - 65.

[15] Diab, N. (2010). Effects of peer- versus self-editing on students' revision on language errors in revised drafts. System 38, 8595.

[16] Diab, R. (2000). Political and socio-cultural factors in foreign language education: The case of Lebanon. Texas Papers in Foreign Language Education 5.1, 177-187.

[17] Diab, R. (2006). University students' beliefs about learning English and French in Lebanon. System 34, 80-96.

[18] Diab, R, (2009). Lebanese EFL teachers' beliefs about language learning. TESL Reporter, 42.2, 13-34.

[19] El-Hussari,I. (2007). Promoting the concept of social awareness as a curricular objective in the EFL/ESL setting: A case study of policy and practice. 1st Mediterranean Graduate Students Meeting in Linguistics, 25-26 October, Mersin, Turkey.

[20] Frayha, N. (1999). The rationale behind language preference in schools and universities in Lebanon. Presentation at the Michigan Award Ceremony organized by the American Language Center and hosted at the Lebanese American University.

[21] Frayha, N. (2003). Education and social cohesion in Lebanon. Prospects 23, 87-89.

[22] Ghaith, G. and K. Shabaan (1996). Language-in-education policy and planning: The case of Lebanon. Mediterranean Journal of Educational Studies 1.2, 95-105.

[23] Ghosn, I. (2007). Output like input: Influence of children's literature on young L2 learners' written expression. In B. Tomlinson (ed.) Language acquisition and development studies of learners of first and second languages. London: Continuum, $171-186$.

[24] Greenfield, W. \& Akkary, R. (1998). Leadership and work context of public and private secondary schools in the republic of Lebanon. Paper presented at the annual meeting of American educational research association, April San Diego, CA.

[25] Haidar, N.F. (2002). Lebanon as a regional educational and cultural center. In K. C. Ellis (ed.) Lebanon's second republic prospects for the twenty first century. Gainesville: University Press of Florida, 140 - 145.

[26] Inati, S. (1999). Transformation of education: will it lead to integration? Arabic Studies Quarterly 21.1, 55-68.

[27] Jarrar, S., J. Mikati, and B. Massialas (1988). Lebanon. In G. Kurian (ed.) World education encyclopedia. New York: Facts on File Publications, 778 - 796.

[28] Joseph, J.E. (2004). Language and identity: National, ethnic, religious. New York: Palgrave Macmillan.

[29] Joudi, D., S. Karaky, and R. Kurdi (2003). Child talk: analysis of cultural influences on content and style. In R. Bahous \& N. N. Bacha (eds.) Proceedings of second regional conference on language and change. Beirut: Librarie du Liban, 109 - 120.

[30] Khoury, M. R. (2003). The teaching of culture: large vs. small culture views. In R. Bahous and N. N. Bacha Proceedings of second regional conference on language and change. Beirut: Librairie du Liban, 128 - 139.

[31] Kibbi, I. (2003). Lebanese and American educational differences: a comparison. Education 11.3, $441-419$.

[32] Maalouf-El Alfy, M. (2000). The impact of culture on the teaching of English literature. In N. N. Bacha \& R. Bahous (eds.) Proceedings of the first regional conference on language and change. Beirut: Librarie du Liban, 66 - 77.

[33] Mikati, M. (2000). Higher level skills in the new Lebanese curriculum. In N. N. Bacha \& R. Bahous (eds.) Proceedings of the first regional conference on language and change. Beirut: Librarie du Liban, 41 - 48.

[34] Moussaoui, R. (2009). French takes backseat to English among Lebanese citizens. Agence France Press, retrieved http://www.dailystar.com.lb/article.asp?edition_id=1\&categ_id=1\&article_id=100264- March 23. (accessed 30/10/2010).

[35] Nasr, N. (2000). Globalization and the preservation of cultural distinction. In N. N. Bacha \& R. Bahous (eds.) Proceedings of the first regional conference on language and change. Beirut: Librarie du Liban, $49-60$.

[36] Nasser, R.N. \& C. A. Goff-Kfouri (2008). Assessment of the English remedial programme at a private university in Lebanon. Mediterranean Journal of Educational Studies 13.1, 85-100.

[37] Nauffal, D.I. \& R. N. Nasser (2007). The American higher educational model in Lebanon: Organizational cultures and their impact on student outcomes and satisfaction. Mediterranean Journal of Educational Studies 12.1, 43-65

[38] Saad Khalaf, R. (2009). Youthful voices in post-war Lebanon. The Middle East Journal 63.1, 1-13.

[39] Serriyeh, H. (1989). Lebanon: Dimensions of conflict, Adelphi papers 243. Oxford: Nuffield Press. 
[40] Shaaban, K. \& G. Ghaith (1997). An integrated approach to foreign language learning in Lebanon. Language, Culture \& Curriculum 10.3, 200-207.

[41] Shaaban, K. \& G.Gaith (1999). Lebanon's language-in-education policies: From bilingualism to trilingualism. Language Problems and Language Planning 23, $1-16$.

[42] Shaaban, K. \& G. Ghaith (2002). University students' perceptions of the ethnolinguistic vitality of Arabic, French and English in Lebanon. Journal of Sociolinguistics 6.4, 557-574.

[43] Sinno, Z. S. (2008). The impact on language learning of Lebanese students' attitude towards English in the context of globalization and anti-Americanism. Unpublished Doctorate Thesis, University of Leicester, U.K.

[44] Yazigi, R. (1994). Perceptions of Arabic as native language and the learning of English. Language Learning Journal 9, 68 - 74.

[45] Zachs, F. (2005). From the mission to the missionary: The Bliss family and the Syrian Protestant College (1866-1920). De Welt des Islams 45.2, $255-290$.

[46] Zakharia, Z. (2004). How schools cope with war: A case study of Lebanon. In D. Burde (ed.) Education in emergencies and post-conflict situations: Problems, responses, and possibilities. New York: Society for International Education Teachers College, Columbia University, 107 - 117.

[47] Zouain, G, (1994). Lebanon: Systems of education. In T. Husen and T. N. Postlethwaite (eds.) The international encyclopedia of education. Oxford: Pergamon, 3349 - 3356.

Nahla Nola Bacha has a Ph.D. in Applied Linguistics and TESOL from the University of Leicester, UK. She is currently an Associate Professor in English and the Assistant Dean of the School of Arts and Sciences at the Lebanese American University in Byblos, Lebanon.

She has published extensively in the field of English language teaching and learning. Some of her publications are Bacha, N. N. (2011) Teaching EFL/ESL Students Critique Writing In Pennington and Pauline Burton (Eds.) In The College Writing Toolkit: Tried and Tested Ideas for Teaching College Writing (pp.251-280). London: Equinox Publishers; Bacha, N.N. \& Bahous; R.(2010). Student and teacher perceptions of plagiarism in academic writing. Writing and Pedagogy 2(2), 251- 280. Bacha, N.N. Teaching the academic argument in an EFL environment. International Journal of English for Academic Purposes. 9, 229-241.

Her current research interests are in academic writing at the university level in the EFL/ESL classroom.

Rima Bahous has an Ed. D. in Applied Linguistics and TESOL from the University of Leicester, UK. She is currently an Associate Professor in Education and the Director of the Center for Program and Learning Assessment at the Lebanese American University in Beirut, Lebanon.

Some of her publications are Bahous, R. \& Nabhani, M. (2011). Assessing education program learning outcomes. Educational Assessment, Evaluation and Accountability, 23(1), 21 - 39; Nabhani, M. \& Bahous, R. (2010). Continuing professional development in Lebanese schools. Teacher Development 14(2), 207 - 224; and Fidaoui, D., Bahous, R., \& Bacha, N.N, (2010). CALL in Lebanese elementary ESL writing classrooms. Computer Assisted Language Learning 23 (2). 151 - 168.

Her current research interests are in program and learning outcomes assessment. 